\title{
ウルトラマイクロ電極の作製とその挙動
}

\author{
阿部 孝之*, 末永 智一*, 内田 勇*
}

\section{Fabrication of Ultramicroelectrodes and Their Behavior}

Takayuki ABE*, Tomokazu MATSUE* and Isamu UCHIDA*

Key Words : Ultramicroelectrode, Electropolishing, Pt, Au, Carbon

\section{1. 緒言}

一般にマイクロ電極之は電極直径 $100 \mu \mathrm{m}$ 以下の金属 電極を示す。このマイクロ電極が, 最近の電気化学測定 において大変脚光を浴びてきている。本来マイクロ電極 は1970年代前半に電気生理学の分野で誕生したものであ るが ${ }^{1}$, 通常サイズ $(\mathrm{mm} \sim \mathrm{cm})$ の電極にはない下記 のような興味ある特徴により新しい電気化学測定法とし て注目されてきている2)。

1 ) 測定される電流值は通常の測定条件においては定常 值であり, 複雑な解析を必要としない。

2 ) 測定される電流值は電極面積 $\left(\pi a^{2}\right)$ に比例する のではなく, 電極半径 $(a)$ に比例するので二重層 充電に起因するノイズ（非ファラディ電流）の影響 を除去できる。

3 ）測定電流值が微小（pA〜nA）になるため測定され る電位中の $i R$ 降下分が無視でき, 支持電解質フリー の系にも適用できる。

4) 電極サイズが微小であるため, ミクロな領域での測 定が可能である。

5 ) 電極表面への物質移動が定常であり, かつ高速であ る。

しかしながら,これらマイクロ電極の特徴は電極径が 小さくなるにつれ，さらに助長されていくにあかかわら ず電極の微小化への研究はあまり行われていない。

既に我々は, 直径 $1 \mu \mathrm{m}$ 以下のウルトラマイクロディ スク電極の簡便な作製法 ${ }^{3)}$ (4) について報告したが，今回 はさらに微小な電極の作製法を試み，直径 $100 \AA ̊$ の白金 電極上でのボルタムグラム測定に成功したので報告する。

\section{2. 方 法}

電極となる金属細線の作製法は基本的には我々が既に

* 東北大学工学部（甬980 宮城県仙台市荒巻字青葉）

Fac. of Eng., Tohoku Univ. (Aramaki-Aoba, Sendaishi, Miyagi 980)
報告した方法3), 4) と同じであり, Field emission microscopy のチップ作製に用いられている電解研磨法を 使用した。なお実験で使用した金属線はPt, $\mathrm{Au}$, カー ボンであるがここでは特にPtを中心に説明する。

まず，市販の直径 $65 \mu \mathrm{m}$ のPt線を適当な長さ $(2 \mathrm{~cm}$ 程度）に切りアセトンで洗浄後, 表 1 に示した $\mathrm{NaNO}_{3}$ $: \mathrm{NaCl}=4: 1 \mathrm{wt} \%$ の溶融塩中で方形波を用いて電 解研磨を行った。なお溶融塩の温度は $330^{\circ} \mathrm{C} \pm 10^{\circ} \mathrm{C}$ に規 制した。対極としては溶融塩の容器であある白金ルッボ を用いて，動作極であるPt線はルッボの中心に位置す るようにした。これにより電解時における電流分布は, ほぼ一様であると考えられる。数多くの実駼結果により $\mathrm{Pt}$ 線に印加する電圧により研磨後のPt線の形状と表面 状態に大きな違いがあることが認められた。光学顕微鏡 及び電子顕微鏡の所見より印加電圧が $1.0 \sim 3.5 \mathrm{~V}$ の間 で電解研磨を行うのが最す良いことがわかった。

図 1 は直径65 $\mu \mathrm{m}$ のPt線を先に示した溶融塩中で $2.5 \mathrm{~V}$ の方形波を用いて電解研磨した後のSEM像である。 上の写真の倍率は 10,000 倍であり下の写真は 50,000 倍で ある。

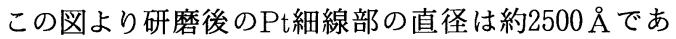
ることがわかる。さらに, Pt表面は極めて滑らかであ りほぼ同径の部分が数 $\mu$ m以上にわたって続いているこ

Table 1 Wire polishing solutions and conditions.

\begin{tabular}{l|l|c}
\hline metal & \multicolumn{1}{|c|}{ solution } & condition \\
\hline \hline Pt & $\begin{array}{c}\text { molten salt } \\
\left.\mathrm{NaNO}_{3}: \mathrm{NaCl}=4: 1 \quad \text { wt } \%\right)\end{array}$ & $\begin{array}{c}1.0 \sim 3.5 \\
(\mathrm{~V})\end{array}$ \\
& $\begin{array}{l}1 \text { gm KCN }+5 \mathrm{~mL} \text { conc.aq.sol. } \mathrm{NH}_{4} \mathrm{OH} \\
+5 \mathrm{~mL} \text { glycerine }\end{array}$ & $\begin{array}{c}1.0 \sim 2.0 \\
(\mathrm{~V})\end{array}$ \\
\hline $\mathrm{Au}$ & $\begin{array}{l}\mathrm{HCl}: \mathrm{HNO}_{3}=1: 1 \\
20 \% \mathrm{KCN} \text { aq.sol }\end{array}$ & $\begin{array}{c}1.0 \sim 2.5 \\
(\mathrm{~V})\end{array}$ \\
\hline $\mathrm{C}$ fiber & $3 \mathrm{~N} \mathrm{KOH}$ & \\
\hline
\end{tabular}




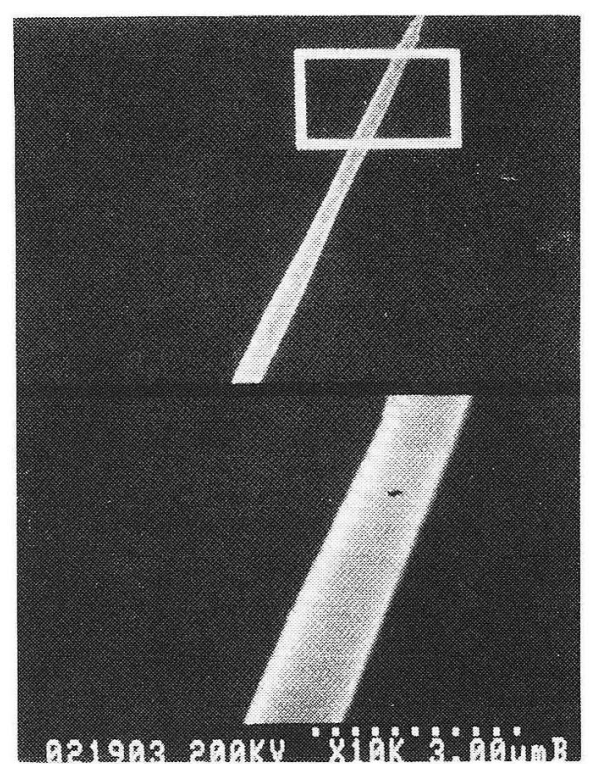

Fig. 1 A scanning electron micrograph of the Pt wire. The upper photograph was taken at a magnification of 10,000 , the lower one was taken at a mag nification of 50,000 .

とあわかる。ちなみに $3.5 \mathrm{~V}$ 以上の電圧で電解研磨した 場合にはガス発生が溶解と同時に生じるため表面が非常 に荒れてしまい細線を作製できなかった。Auについて は市販の直径 $20 \mu \mathrm{m}$ のAu線を, カーボンについては直 径約 $10 \mu$ mのUCC pitch fiber を用いて表 1 に示した 条件で電解研磨を行い細線を作製した。電子顕微鏡観察 により $\mathrm{Au}$, カーボンとむPt之同様, 作製された細線の 表面は非常に滑らかであった。

以上のようにして作製した細線は溶融させた鉛ガラス を用いて先端部を被覆した後, エポキシ樹脂（日新EM 製のQuetol 812）で包埋し24時間 $60^{\circ} \mathrm{C}$ で重合させた。 電極の切り出しにはダイヤモンドナイフ装着のMT2-B 超ミクロトーム (Du Pont)を使用し, 電極を包埋して いるエポキシ樹脂を厚さ $1000 \AA$ で徐々に切り出すことに より，金属断面を露出させた。このようにして切り出し た断面をマイクロ電極として使用した。電気化学測定は すべてアルミニウム製のシールドボックス中で行い雑音 の影響を最大限取り除いた。また, 測定はポテンシオス タットを使用せずSCEを対極とした 2 極式で行い, 微 小電流測定にはKeithley 427高速電流計を使用した。

\section{3. 結果}

図 2 は先の条件で作製したPtウルトラマイクロディ スク電㥛の $0.5 \mathrm{~N} \mathrm{KCl}$ 中での $5 \mathrm{mM} \mathrm{Mo}(\mathrm{CN})_{8}^{1-の サ イ ~}$ クリックボルタムグラム $(\mathrm{CV})$ である。電流值がピコア ンペアレベルと極めて小さい点に注目されたい。通常の

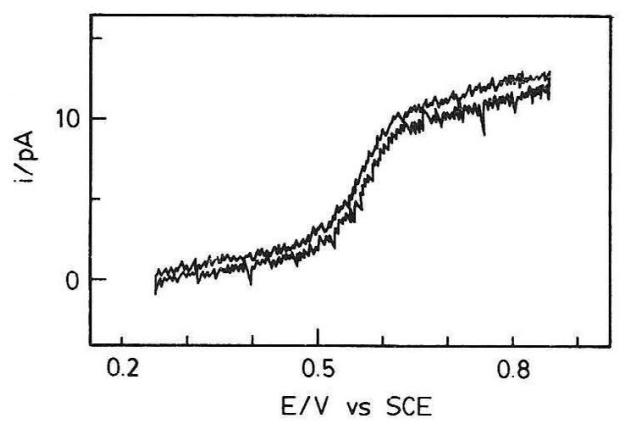

Fig. 2 A cyclic voltammogram of $5 \mathrm{mM} \mathrm{K}_{4} \mathrm{Mo}_{0}(\mathrm{CN})_{8}$ in $0.5 \mathrm{~N} \mathrm{KCl}$ at a Pt ultra microdisk electrode. Scan rate is $20 \mathrm{mV} / \mathrm{s}$.

電気化学測定に丮いられているサイズ $(\mathrm{mm} \sim \mathrm{cm})$ の 電極の場合, 得られるCVにはピークが存在し, そのピー ク電流値は電位の掃引速度に依存する。しかしながら, マイクロ電極はその微小な電極面積ゆえに，短い時間領 域において電極直径ほどの厚さを持つ球面拡散層が形成 される。そのため, 通常の電位掃引速度においては, 図 2 のようにピークが存在しないシグモイド型の定常分極曲 線が得られる。ここで得られた定常電流值 (id) は ${ }^{5}$ )

$$
i d=4 n F C D a \text {. }
$$

で表される。nは反応電子数, $C$ は電極活物質の沖合濃 度，Dは活物質の拡散定数，aは電極半径をそれぞれ表 す。(1)式を用いてここで得られた定常電流值よりこのウ ルトラマイクロ電極の電極半径を見積ったよころ $a \fallingdotseq$ $100 \AA$ という值を得た。図 2 の分極曲線から $\log 〔(i d-i)$ $/ i$ vs. 電位 $(F)$ をプロットするとその傾きは $66 \mathrm{mV}$ と なった。このネルンスト勾配 $(59 \mathrm{mV})$ からのずれは電極 径が極度に小さくなったことにより電極反応速度の影響 を受けたためであると思われる。

$\mathrm{Au}$ ，カーボンについても電極直径サブミクロンオー ダーのウルトラマイクロ電極を比較的容易に作製できる ことが実験結果よりわかっだ)。以上より電解研磨法は ウルトラマイクロ電極の簡便な作製法であると言える。

(1988-9-14 受理)

\section{文献}

1) R. N. Adams; Anal. Chem., 48, 1129A (1976)

2) S. Pons, M. Fleischmann ; Anal. Chem., 59, 1391A (1987)

3) K. Itaya, T. Abe, I. Uchida ; J. Electrochem. Soc, 134, 1191 (1987)

4) T. Abe, K. Itaya, I. Uchida; Chem. Lett., 3, 399 (1988)

5 ) K. Aoki, K. Akimoto, K. Tokuda, H. Matsuda ; J. Electroanal. Chem. Interfacial Electrochem., 171, 219 (1984) 